\section{М.В. Андреева}

Государственный медицинский университет, Волгоград

\section{ЭКОЛОГИЧЕСКИЕ ФАКТОРЫ ФОРМИРОВАНИЯ РЕПРОДУКТИВНОГО ЗДОРОВЬЯ ЖЕНЩИН ВОЛГОГРАДСКОГО РЕГИОНА}

Комплексное исследование состояния здоровья женшин и их детей в условиях Волгоградского региона в динамике 25-летнею наблюдения выявизо достоверную зависимость нарушений соматического, репродуктивного и неонатального здоровья от величины и длителыности экологической нагрузки в районе проживания. Установлено, что с увеличением продолжительности воздействия высокого уровня загрязнения атмосферного воздуха ксенобиотиками состояние здоровья женшин и их детей ухудшается, т. е. выявлен эффект накопленного неблагоприятного действия ксенобиотиков. Это подтверждено полученными регрессионными моделями высокой статистической значимости, доказавшими достоверную связь между всличиной и цителыюстью экологической нагрузки в районе проживания и основными показателями здоровья женской и неонатальной популяций. Эти модели являются основой для прогнозирования частоты выявленных нарушений от степени экологической нагрузки.

Представленная работа является частью вклада в решение очень актуальной проблсмы - экологичсской репролуктологии на уровне Волгоградского региона, имеюшей своей целью улучпить соматическое, репродуктивное здоровье женшин и здоровье их детей, что, в конечном итоге, будет способствовать стабилизации демографической ситуащии.

В последние 15 лет в Волгоградском регионе, как и во всей России, несмотря на спад промышленного производства и улучшение экономической обстановки, происходят глубокие нарушения процессов воспроизводства населения. Эги лроцсссы являются проявлением серьезньх нарушений репродуктивного здоровья женской популяции региона, обусловливающих высокие уровыз материнской, младенчсской заболеваемости и смертности.

Отсюда особую важность лриобретают исследования по изучению релродуктивного здоровья жеишин фертильгого возраста и здоровья их потомства, проживаюших в таком крупном промышленном регионе, как Волгоградский. В этих условиях на них дсйствует весь комплекс неблагоприятных факторов окружаюшей среды - экологических, социальных, экономических и других. Современным женшинам приходится сталкиваться с такими воздействиями вредных факторов, к которым у них не выработалось адаптации в процессе эволюции, что и приводит к формированию патологической функциональной системы peryляции их репродуктивњой функции. Именно состояние репродуктивной системы женшины и здоровье рожденного поколения являюгся наиболес информативными ннтегральными показате:ıми, отражающими воздействие комплекса неблагоприятных факторов среды. Рецродуктивное здоровье - это лревнейлая и наиболсе устойчивая функция, направленная на сохранение биологического вида. Нарушение ес свидетельствует о крайне неблагоприятных условиях, в которых находится женщина. Проявление женской экозависимой патологии обуславливает, в пер- 
вую очерегь, качество ес репродуктивной функпии. А это ужс категория нашиональной стратегии государства.

Какие же доминирующие факторы окружаюшей срелы огрицательно влияют на релродуктивную систему женшин, вызывая ее патологию? По данным ВОЗ доминирующими факторами следует считать состоянис окружающей срелы и образ жизни, поскольку влияние на наследственность пока вие возможностей сонременной науки.

В связи с этим целью нашего 25-летнето исследования явилось изучсние состояния репродуктивного здоровья женщин и здоровья их потомства, три поколения которых проживали и ıроживают в экологически неблагоприятных условиях дтя разработки в последующем комплекса лечсбно-профилактических меролриятий по снижению частоты выявленных нарушений.

Проведенные нами исслсдования доказали, что экологические факторы являются одлими из ведущих в формировании патологии репродуктивной системы женшины. Почему же так происходит?

Установлено, что с 1966 года нацг регион, в первую очередь Волгограл и г. Волжский, относятся к городам с высоким и очень высоким уровнсм загрязнения атмосферного воздуха химичсскими токсикантами - ксенобиотиками Большинство из них (оксиды азота, диоксид серы, сероуглерод и др.) относятся к венествам 2-3 ктасса опасности и вызывают отдаленныс отрицательные последствия. Более половины из них постулают в организм чсловека через легкие, которые не имеют химического заслона. Мы же дышим этим воздухом постоянно. По мнению наших ведуциих ученых - Э.К. Айламазяна, В.Н. Серова, Н.Н. Ваганова, именно техногенная агрессия окружающей среды, в первую очерсдь, снижает качество репродуктивной функции женниин. Это и было доказано нашими исследованиями.

Наименьшая частота нарушений соматического, репродуктивного здоровья выявлена у жительниц наиєего региона I поколения, рожавших в 1978 году. У них эффект накопленного неблагоприятиого воздействия комплекса ксенобнотиков был минимальным (12 лет). Наколленный комплексный индекс загрязнсния атмосферы (КИЗА-ІІ) составил 30. Наибольший рост патологии соматического и репродуктивного здоровья выявлен у жительниц пашего региона в пачале 2000 -х лодов, когда длительность эффекта наколленного действия химических вешеств составила более 35 лет. КИЗА-Н при этом вырос в районах обследования почти в 10 раз (рис. 1).

Этим можно обьяснить значительный рост заболеваемости населсния в регионе после 1988 году, особенно беременных женшин, как наиболес чувствительной популяции к дтительному воздействию химических токсикантов.

Это также подтверждается результатами анализа медико-демографических показателей, характеризующих здоровьс женской популяции нашего региона за 25 лет.

Были выявлены основные тенденции деформации здоровья женской и детской популящий (рис. 2). Это резкое снижение рожілаемости и увеличение смертиости; дислропорция полов в сторону увеличения числа женшин; снижение возрастной интенсивности деторождения за счет уменыления количества девочек до 15 лет на $6,4 \%$ и женицин активного релродуктивного возраста (20-29 лет) на $18,7 \%$ на фоне увеличения числа женшин пострепролуктивного возраста; уменьшение числа зарегистрированных браков, рост разводов (в начале 2000-х годов на 1,5 брака приходился ( развод); большое количество абортов, в 2 раза превышаюшее число родов; формирование нового типа репродуктивного поведения населения с ориентацией на однодетную семью и достаточно быстрое завершение генеративной функции к 30-ти годам. Выявлены iлубокие нарушения адаптационного гомеоста$\mathrm{ra}$, проявляюшиеся в «омоложении» смертности среди женского населения младшего и среднего репродуктивного возраста за счет увеличения смертности юных (15-19 лет) и мололых женщии (20-35 лет); смертность в этих возрастных группах женшин возросла в 2003 году по сравнению с 1980 годом в 2 раза (рис. 3,4 ). 3арегистриронаны высокие уровни материнской, младенческой смертности без явной тенденции к снижению. Высокий уровень материнской смертности в регионе за последние 15 лет обусловлел в основном высокой частотой экстрагенитальной патологии, гсстозов, которые в структуре материнской смертности составили $30-50 \%$. Это связано с тем, что за последние 15 лет частота различных форм экстрагенитальной, акушерско-гинекологической патологии в регионе возросла от 2 до 35 раз. Экстрагениталыные заболевания в настоящее время зарегистрированы у $94,8 \%$ беремснных женцин, акушсрская патология - у $83,2 \%$.

Высокий уровень младенческой смертности в регионе обусловлен, в основном, эндогенными лричинами. Следствием этого является высокий удельный вес неупранляемых причин 


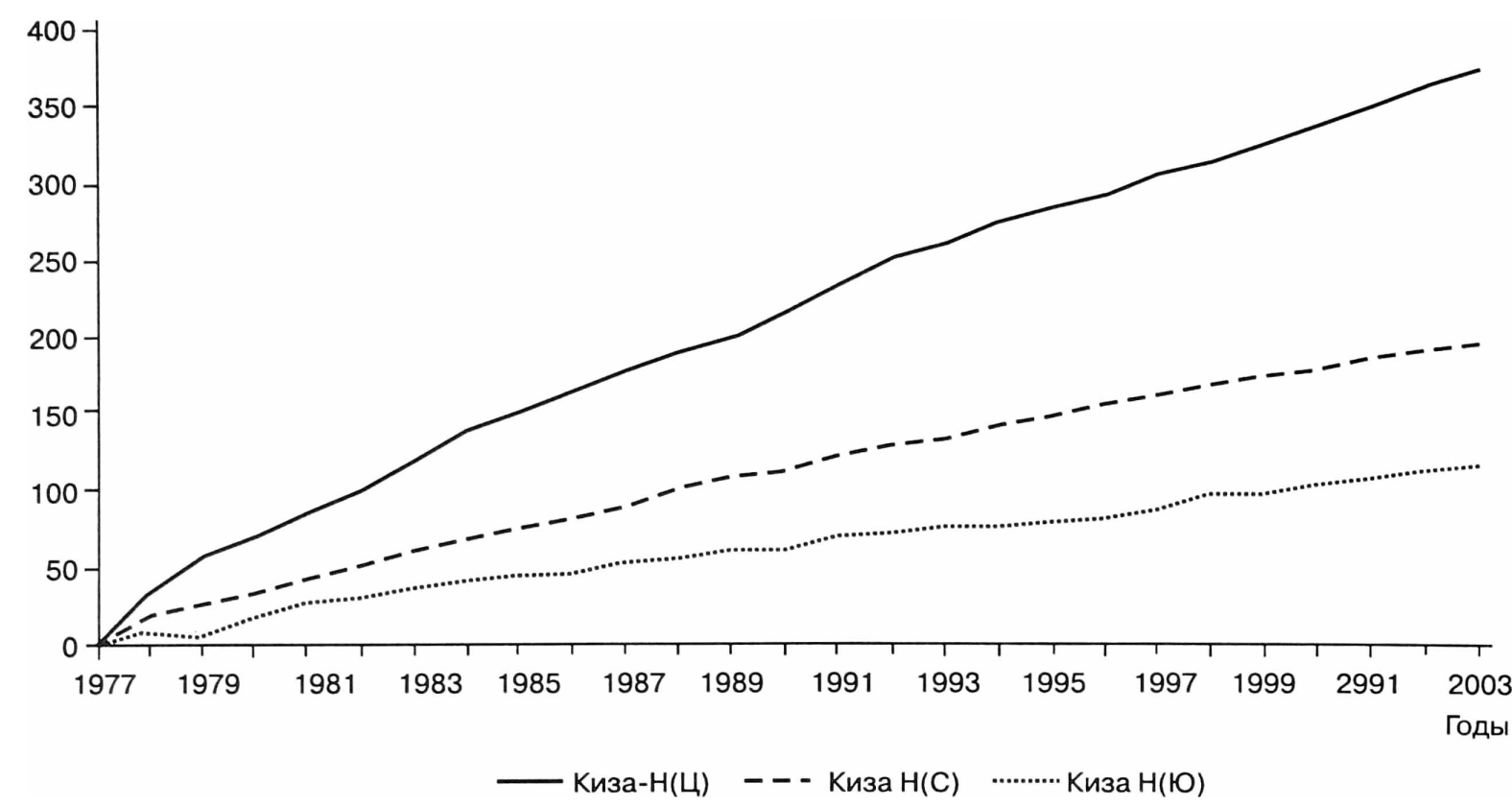

Рнс. 1. Накопленный көмплексный индекс загрязнення атмосферы КИЗА-ІІ в районах об́следования Волгогралского региона

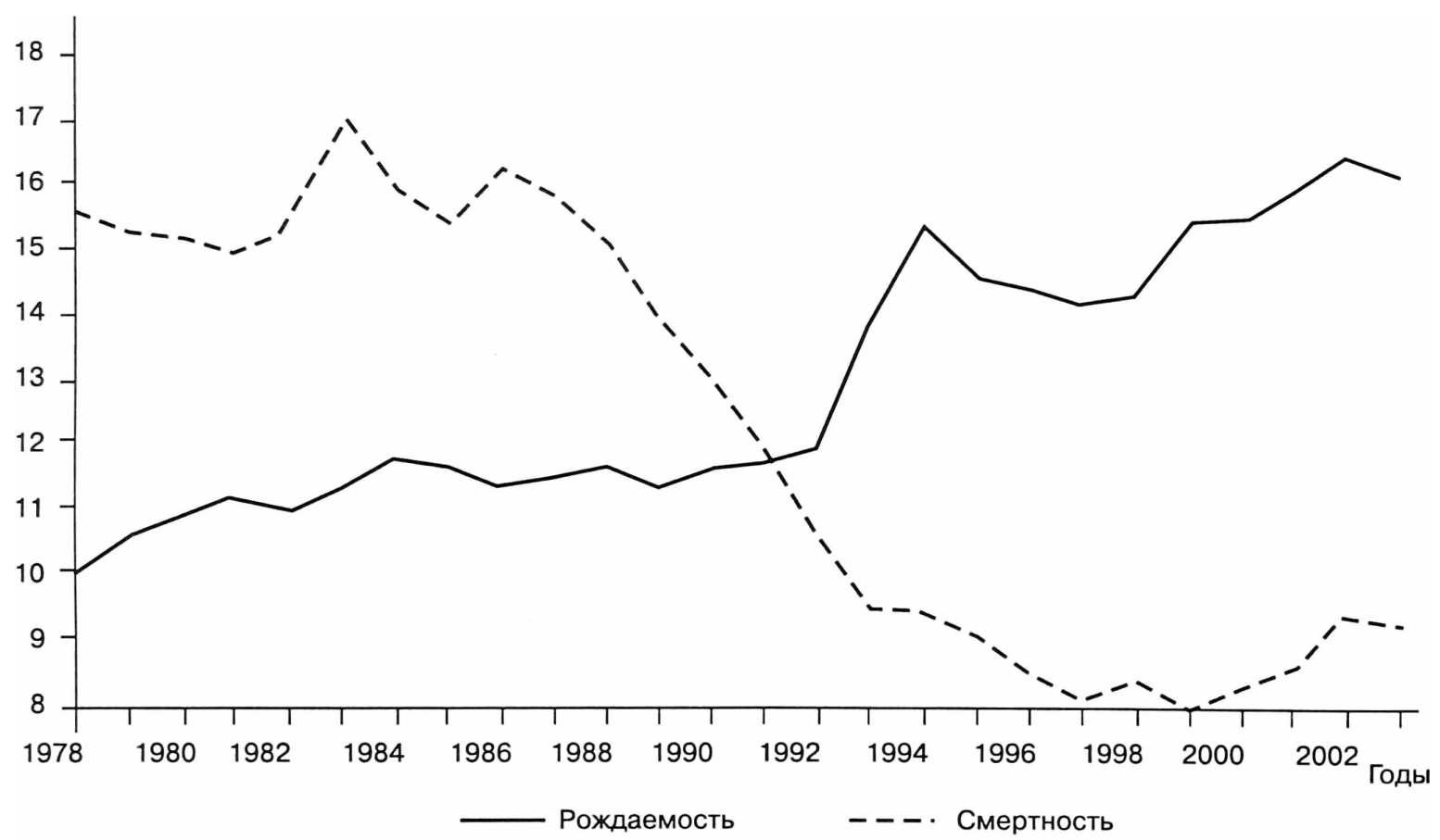

Рис. 2. Обтьке коэффитиенты рождаемости и смертности (на 1000 человек населения) Волгоградской области

младенческой смертности - врожденных пороков развития, которые в последние 15 лет занимают второе место в регионе в структуре причин младенческой смертности и составляют $8,6 \%$.

Наши собственные исследования показали следуюшее. За 25 лет наблюдения здоровье беремен- ных женщин в регионе значительно ухудшилось (рис. 5). Часгота экстрагенитальной патологии увеличилась в 2,5 раза (с 39,3 до 94,8\%). В наибольшей степени возросли (рис. 6) анемии (69,7\%), болезни органов дыхания $(46,3 \%)$, эндокринной $(34,2 \%)$, нервной $(23,1 \%)$ и мочевыделительной систем $(20,1 \%)$. Наибольшая частота их была в 
г. Волжском, как наиболее экологически неблагополучном.

Полученные данные пренышают нопуляционные показатели почти на 50\%, что свидетельствует о нарушениях в биосистеме «мать», которая изначально не в состоянии обеспечивать оптимальные условия развития плода. На этом фоље за 25 лет в 2,4 раза увеличилась частота осложнений беременности (рис. 7). Частота угрозы грерывания беременности увеличилась почти в 3 раза $(50,1 \%)$, гестозов в 2 раза $(47,2 \%)$, генитальных инфекций - в 5 раз $(45,1 \%)$. У кажлой беремен- ной регистрировалось не менее 3-х видов патологии. Наибольшая частота акушерских осложнений выявлена в $\mathrm{r}$. Волжском.

Академиками В.Н. Серовым, Э.К. Айламазяном доказано, что нарупение процессов алаптации у беременных женшин является ответом организма на хронический экологический стресс.

В связи с этим нами быја оценена стелень адапгтация беременных Волгоградского региона за 25 лет (рис. 8). Выявлено нарушение процессов адаптации в виде неудовлетворительной адаптации и срыва ее у $48,6 \%$ беременных в на-

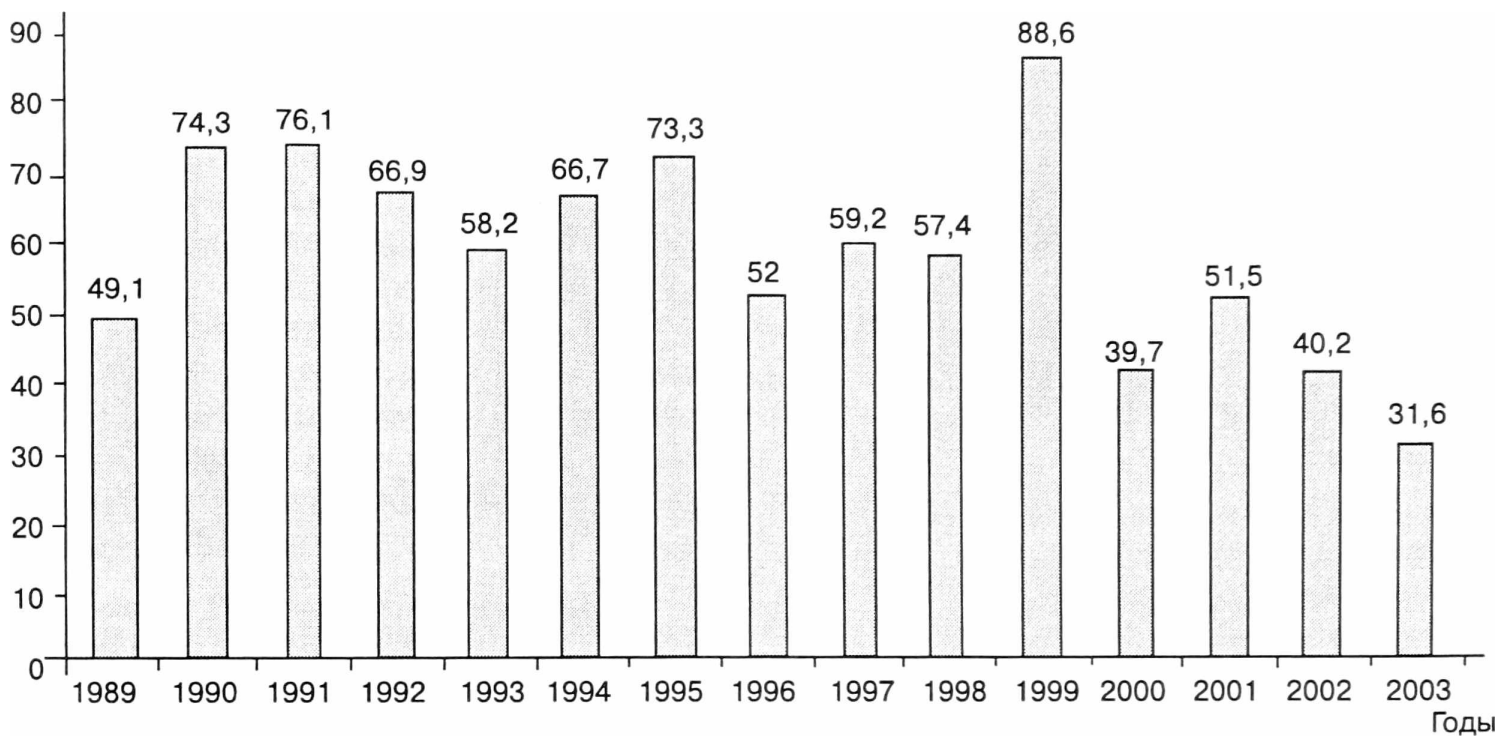

Рис.3. Динамика материвской смертности в Волгоградекой области (на 100000 жнворожденных)

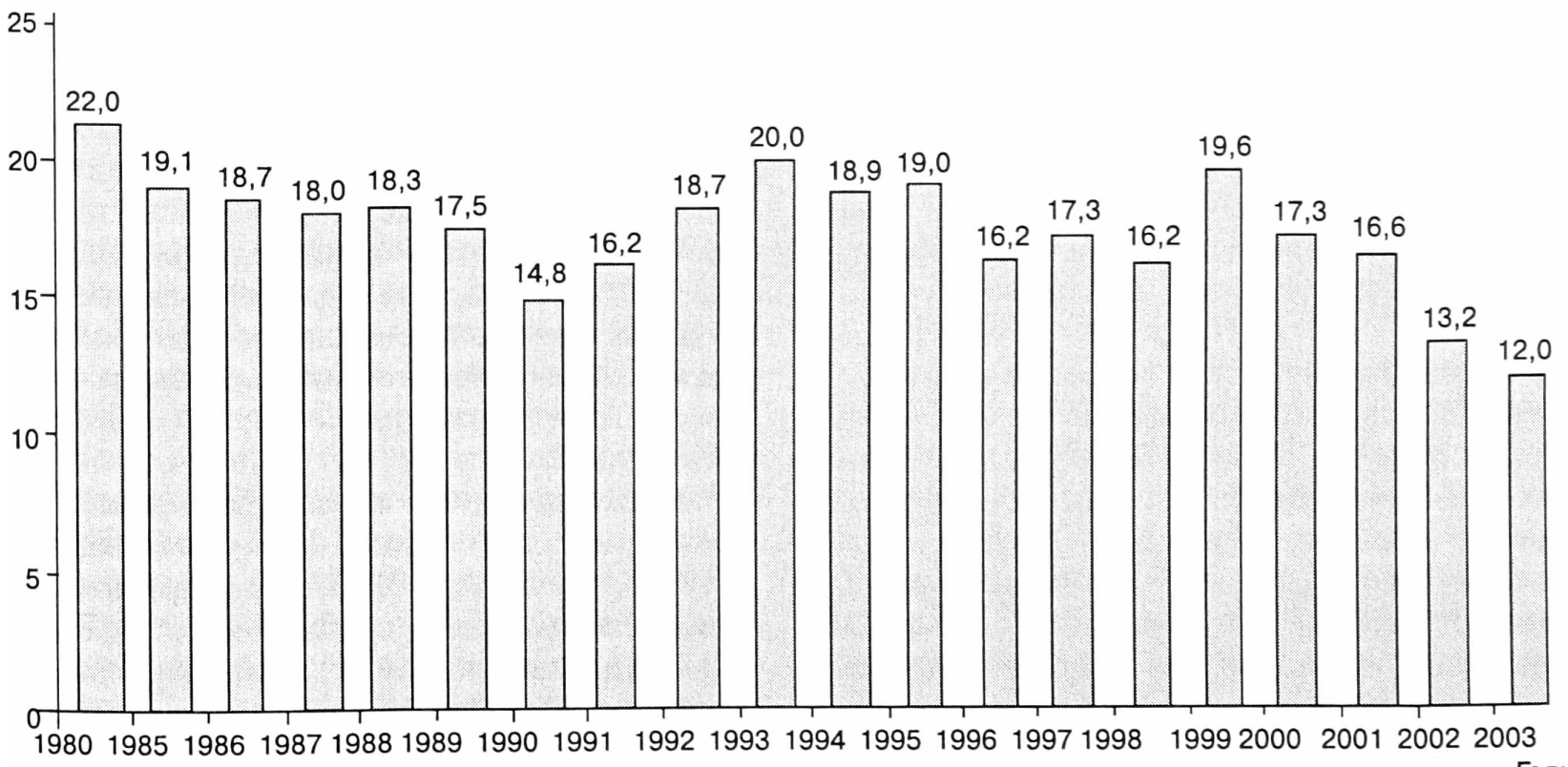

Рис. А. Динамнка м.ладенческой смертности в Волгогралской области (на 1000 родившихся жнвымя) 


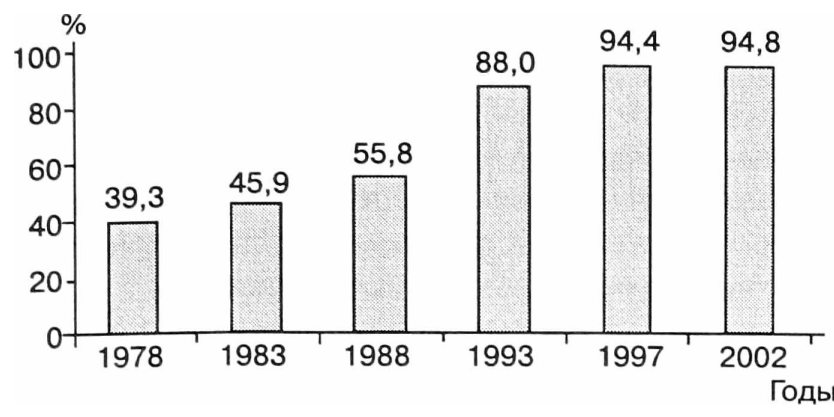

Рис. 5. Частота экстрагенитальной заболеваемости беременных женщин Волгоградского региона в динамике 25-летнего наб̈людения

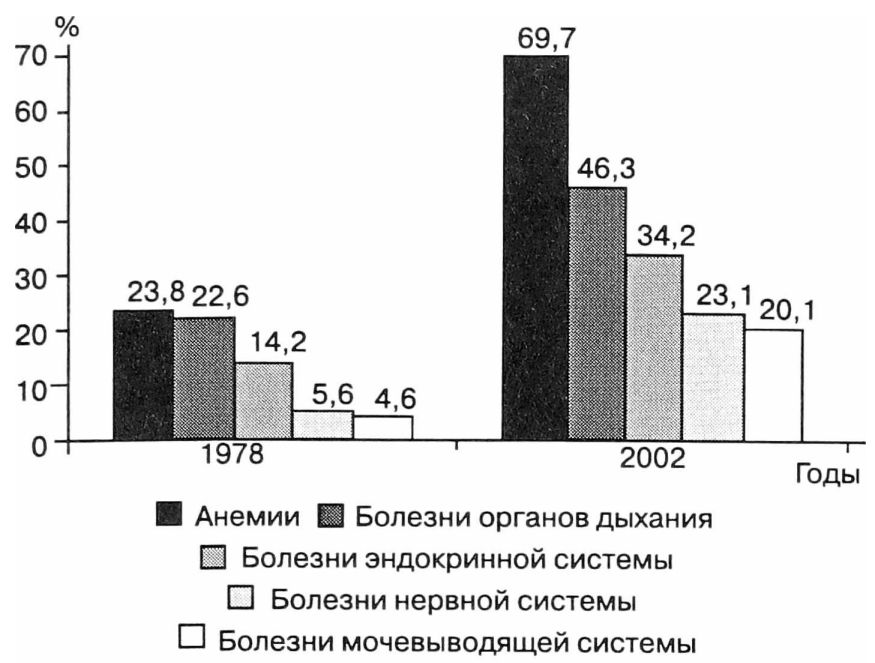

Рис. 6. Частота основньх экстрагениталынг заболеваний у беременньг женщин Волгогалского региона за 25 лег наблюдения

чале 2000-х голов. В конще $70-x$ годов проицлого столетия таких беременных было всего $19,5 \%$.

В связи с этим в 3 раза возросла (рис. 9) по численности грушша женшин высокого риска ло акушерской патологии во время гестации и в родах, которая составила в регионе в начале $2000-x$ годов $71,8 \%$ (в 70-е годы $-21,4 \%$ ).

Психическая адаптация - одна из наиболее важных составляюших обшего адаптационного процесса. При воздействии на организм неблагоприятных факторов внешней среды она нарушается в первую очередь. В начале 2000 -х годов среди беременных напего региона неустойчивый психоэмоциональный статус диагностирован в $81,2 \%$ случаев в видс астено-невротического (АНС) и ипохондрического (ИІТ) синдромов. Это является фоном для развития осложнений во время беременности и в родах.

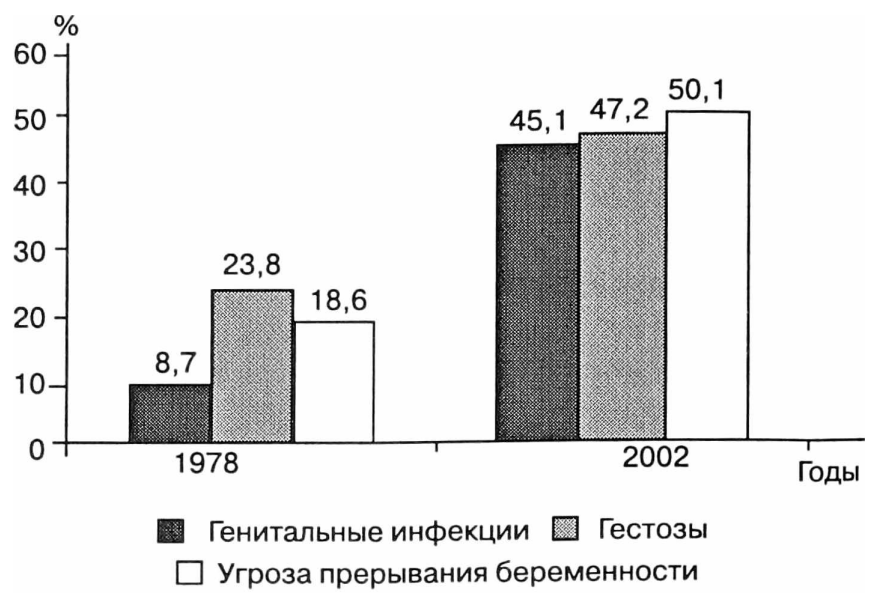

Рис. 7. Частота основных осиожнений бсременности у женщин Волгоградского региона за 25 лет иаблюдения

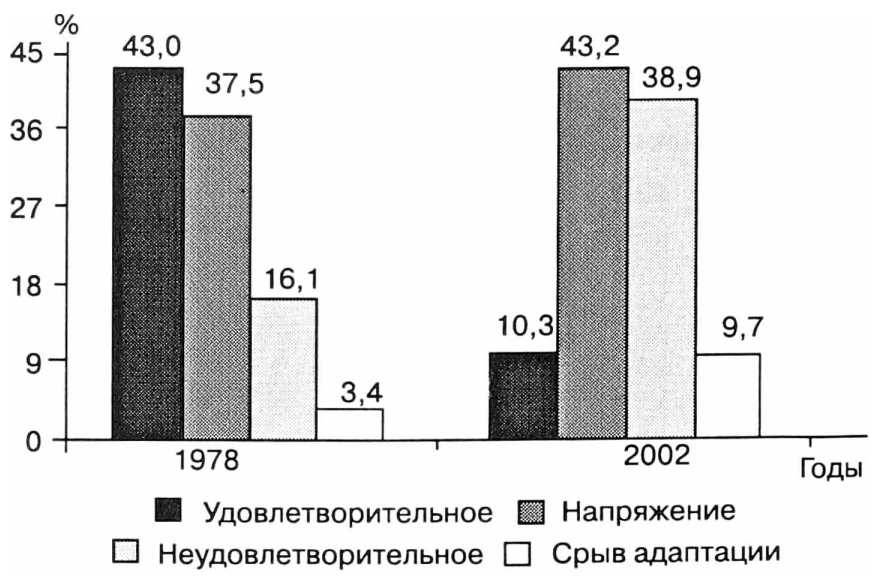

Рис. 8. Динамнка изменения частоты различной стешени адапташии в I триместре беременности у женшин Волгоградского региона

Выявлениый нами высокий уровень угрозы прерывания беременности, токсикозов в ранние сроки у жительниц нашего региона свидетельствует о ранием формировании у них нарушений в системе мать-плацента и плод под действисм неблагоприятыьх факторов внешнсй среды. Известно, что в основе возникновения большинства осложнений беременности, родон, патологии плода лсжит развитие плацентарной недостаточности.

Оценка функционального состояния фетоллацентарного комплекса (ФПК) выявила почти у $50 \%$ обследованных беременных признаки развития плацентарной недостаточности (ПН) на основании показателсй У3 плацентометрии, плацентографии (увеличение толщины плаценты в начале и конце бсременности в сравнении со средними значсниями нормы, отставание «зрелости" плаценты в конце беременности или 


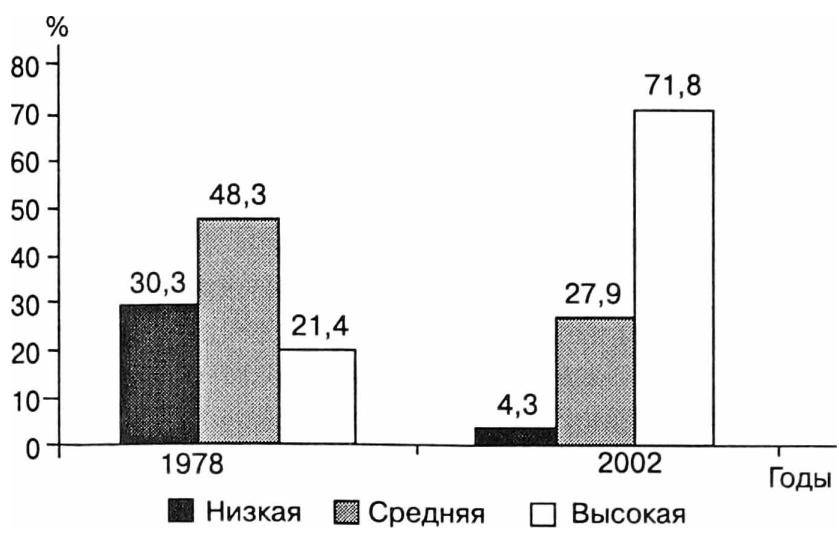

Рис, 9. Динамика распределения обследованных женщин Волгоградского региона по группам риска в конце бсременности

ее преждевременное «созреванис»; эти данные являются ультразвукоными критериями развития ПН у беременных региона) и на основании олределения количественного содержания гормонов в моче в динамике беременности в виде повышения экскреции эстриола с мочой в ранние сроки беременности и уменыпения в конце беременности, а также в значительно меньшей сгепени нарастания ес уровня в динамике беремснности по сравнению со средними значениями нормы.

Патология со стороны плаценты у беременных иодтвердилась также морфологическими исслсдованиями плацент у здоровых родильниц, жительниц районов с разным уровнем тсхногенной нагрузки. Достоверно болыпая частота и выраженность патологических изменений в плацентах, установлена более чем у $50 \%$ женшин районов экологического неблагополучия (РЭН), в районе относитсльного экологического благополучия (район сравнения) - у $25 \%$ родильниц. По-вилимому, это можно расценить как непрямое воздействие высокого уровня химических зајрязнителей атмосферы иа беременную.

Нельзя исключить прямого действия ксенобиотиков, загрязнителей атмосферы РЭН, наэмбрион и плод. Поэтому слелующей задачей было исследование присутствия сероуглерода в биосрелах беременных женшин, жительниц северного, наиболее загрязненного района, и района сравнения. В $17,2 \%$ случаев определялось его присутствие в эмбриональной ткани и крови беременных на севере региона, в $11,4 \%$ случаев - только в крови. У беременных в районс сравнения сероуглерод в биосредах обнаружен не был. Эти факты способствуют пониманию причин нарушения течения беременности, ро- дов, состояния плода и новорожденного. Обнаружение сероуглерода в эмбрионагьной ткани свидетельствует о его прохождении через плаценту и возможности прямого эмбриотоксического действия. Многофакторный регрессионный анализ показал высокую значимость этого ксенобиотика в развитии гестозов, анемии беременных, угрозы ее прерывания у жительниц района с наиболее высокой техногенной нагрузкой.

Обнаруженные нами изменения в плаценте у беременных сочетались с развитием внутриутробной гипоксии плода почти у $50 \%$ обследовалныл. Следствием ПН явилось развитие асимметричной формы гипотрофии плода, выявленной в динамике беременности у женшин путем измерения основных УЗ фетометрических показателей.

Обнаруженные нарушения состояния ФПК были подтверждены также клиническими данными о высокой частоте рождения детей в регионе в асфиксии, с поражением ЦНС, в основном гипоксического генеза, с гипотрофией. Эти нарушения состояния ФПК достоверно чаще наблюдались у беременных жительниц РЭН. Частота их нарастала в динамике наблюдения.

Патологические изменения ФПК отразились на исходах беременности и течении родов. За 25 лет наблюдений частота преждевременных родов увеличилась в 2 раза (с 3,9 до $8,9 \%$ ). Частота своевременных родов уменьшилась на $10 \%$ (с 93,2 до $83,1 \%$ ). Количество физиологических родов сократилось в 4 раза (с 59,3 до $14,1 \%$ ). Частота осложнений в родах 3225 лет увеличилась в 2 раза (с 40,9 до 86,1\%). Превалировали аномалии родовой деятельности $(34,6 \%)$, гестозы $(22,4 \%)$, гипоксия ллола $(22,7 \%)$.

Частота патологии в пуэрлерии за 25 лет наблюдений увеличилась в 2 раза (с 24,2 до $51,3 \%$ ). Преобладали анемия $(41,3 \%)$, субинволюция матки $(20,6 \%)$, генитальныс инфскции $(19,9 \%)$, гипогалактия (17,9\%).

Патологическое течение беременности, родов привели к наруиениям здоровья новорожденных. 3 а 25 лет наблюдения заболеваемость детей в регионе в раннем неонатальном периоде увеличилась в 3,5 раза (с 14,2 до $51,4 \%$ ). Наиболее частыми осложнениями были асфиксия при родах $(43,1 \%)$, поражения ЦНС $(38,3 \%)$, лреимушественно гипоксического генеза $(23,3 \%)$, задержка внутриутробного развития $(18,7 \%)$. Частота ведущих нозологических форм неонатальной патологии превышала в 2 раза популяционные показатели. У новорожленных в начале 2000 -х 
годов наблюдались отклонения физического развития: преобладали дети с низкой массой тела при рождении и с меньшими показателями роста.

Известно, что состояние репродуктивной системы женшины во многом опредсляется состоянисм ее здоровья в подростковом возрасте. С этой целью нами было изучено состояние здоровья девочек-подростков региона.

У девочек-подростков региона зарегистрирован высокий уровень общей заболеваемости и накопление хронической патолюгии с возрастом. Наиболее высокий показатель заболеваемости у них ныявлсн в 18-19 лет, преимущкественно у жительнил РЭН. У девочек преобладали заболевания органов дыхания, инфекционные 6олезни, заболевания органов пишеварения. В структуре гинекологической заболеваемости преобладали нарушения менструальной функции. Они наблюдались у $54,2 \%$ девочек региона, преимушественно в РЭН.

В периоде полового созревания девочки РЭН отставали в физическом и половом развитии от своих сверстниц из района сравнения. У них наблюдался больший рост при меньших размерах массы тела, окружности груди и костного таза, более поздний возраст наступления менар$\mathrm{xc}$, более позднее и менес интенсивюое развитис вторичных половых признаков при достоверно замелленном формировании костного таза по женскому типу и больней частоте нарушений менструального цикла.

Пубертатный период у девочек региона протскал на фоне изменения гсихической адаттации в виде наруптения психоэмоциональноло профиля личности (ПЭПЛ) у $73,4 \%$ обследованньх с преобладанием астено-невротического синдрома (AНС) у 62,3\%. Девочки с ипохондрическим синдромом (ИПС) составили $11,1 \%$. Психоэмоционально устойчивый профиль личности (ПЭУ) выявлен всего у 26,6\% девочск. Установлена связь между частотой различных форм нарупгений менструального цикла и изменением психоэмоционального статуса. У девочек с АНC чаше всего наблюдалась гинерполименорея, с ИПС (более тяжелая форма нарушения менструального цикла) - гипоолигоменорея. Эти патологические изменения наиболее часто и в наиболее тяжелых формах регистрировались у девочек РЭН.

У девочек выявтена дистония ВНС, выражавшаяся в энергетическом дисбалансе акупунктурных меридианов, ответственных за функциональное состояние соматического, нервно-ऑсихического и репродуктивного здоровья. С помощью многофакторного регрессионного анатиза была установлена корреляционюая связь ПЭПЛ девочек-1 одростков с частотой нарушений у них функций меридианов дыхания, пищеварения и выделения, определенных методом электропунктурной диагностики (ЭПД), В связи с этим есть основание использовать этот метод в качестве скрининга для массовой донозологической диагностики состояния здоровья девочек-Подростков, в том числе психического.

Таким образом, проведенное комплексное исследование состояния здоровья женшин и их детей в условиях Волгоградского региона в динамике 25 лет наблюдения выявило достоверную зависимость нарушений соматического, репролуктивного и неонатального здоровья от величины и лиитељьности экологической нагрузки в районс проживания, что указывает на эффект накопленного неблагоприятного действия ксенобиотиков. Это подтверждено полученными регрессионными модслями высокой статистической значимости, доказавпими достоверную связ, между величиной и длительностью экологической нагрузки в районс прожинания и основными показателями здоровья женской и неонататьной популяций. ЭТи модели являются основой для прогнозирования тастоты выявленных нарушений от степени экологической нагрузки, как минимум, на 5 щет вперел.

На основе результатов исследования нами разработан и внедрен в практику комплекс поэтапных лечсбно-профилактических мероприятий с включением в него методов рефлексотерапии. Это позволило снизить частоту осложнений во время беременности, в родах, пуэрперии и неонатальном периоде (в 2,53 раза), что привело к уменьшению уровня материнской, младенческой заболеваемости и смертности в регионе.

Комплекс лечебно-профилактичсских мероприятий включал:

I. - Организационныс мероприятия, направленные на улучшение условий жизни, экологической обстановки, оздоровление населения путем формирования здорового образа жизни;

II. - Поэтапные лечебно-профилактические мероприятия в зависимости от величины техногенной нагрузки в районе проживания:

1 этап - догестационная подготовка женпин;

2 этал - профилактика и лечение гестационньх осложнений с ранних сроков беременности;

3 этап - профилактика и лечение осложнений в родах;

4 этап - профилактика и лечение осложнений в пуэрперик; 
5 этап - профилактика осложнений у родильниц в услониях женской консультации, у новорожденных - в условиях детской поликлиники; а также:

III. - Лечебно-профилактические мероприятия, направленные на физиологическое течение пубертата у цевочек-подросткон.

Все эти мероприятия подробно изложены автором в методических рекомендациях, изданных Комитетом ло здравоохранению Администрации Волгоградской области и Волгоградским Государственным медицинским университетом.

\section{Выводы}

Наши исследования показали, что есть песколько причин, привоцящих к высокому уровню нарушений репродуктивного здоровья и материнской смертности.

1. Страдает система дислансерного наблюдения за беременными.

2. Население не ориентировано, что медаборты наюосят огромный ущерб здоровью женщин.

3. Отсутствует культура половой жизни в свсте предотвращения нежелательной беременности, отсутствуют полноценные знания в плане правильного использования современных методов контрацепции.

4. Современная медицина бессильна помочь в тяжелых, залущенных случаях заболеваний беременных. Чащс всего погибают не обследованные и не леченные ранее женшины.

Прсдлагаемые пути профилактики этих патологических иарушений репродуктивной системы девочки, женшины:

- улучшение условий жизни;

- улучшенис экологической обстановки;

- озлоровленис населения путем формирования здорового образа жизни.

\section{Предложения}

- Изменить отношелие населения, в том числе мужского, к аборту. Аборт не должен быть мсрой регулирования рождаемости. Изменить репродуктивное поведение женшин в сторону применения современных эффективных средстн контрацепции.

- Повсеместно проводить ссксуальное воспитание подростков, направленное на пропаганду целомудренного образа жизни, а также на предупреждение нежелательной беременности.

- Постоянно готовить левочек к осознанному материнству, развивать у них заботу о своем здоровье.
- Разработать и внедрить мероприятия по улучшению здоровья всего населения, в первую очередь детей и молодежи, как будущего генофонда нации.

- Пронодить ориентацию среди населения на здоровую семью.

- Укреллять амбулаторную и стационарную службы по медицинскому обслужинанию населения, особенно беременных женпин и девочек-подростков.

- Организовать в каждом районе дневные стационары для лечения беременных.

- Проводить витаминизацию беременных за счет улучшения их питания. Для этого необходимо выделить деньги из Госбюджета для беременных из малообеспеченных семей.

- Необходимо открытие областного или городского отделения шия бсременных с экстрагенигальной патологией. Это можно сделать не за счет сокращения косчного фонда в ролдомах, а за счет перепрофилирования послеродовых отделений.

- Обязательно должно проводиться выделе ние групп риска среди беременных по основным региональным формам экстрагенитальной патологии - анемии, заболеваниям почек и др. В этих грулпах с ранних сроков беременности необходимо проводить ірофилактическое лечение (фитотерапию, витаминизашию, ИРТ).

- Необходимо обеспечить беременных из грулп риска 110 заболеванию почек бесплатными исслелованиями мочи на стерильность, чувствительность флоры к антибиотикам. Ссйчас каждый такой анализ стоит болсе 200 руб.

- В связи с проблемой высокой частоты медицинских абортов, особенно среди молодежи, в том числе по социальным показаниям, необходима бесплатная выдача контрацептивных средств лодросткам из малообеспеченных семей, неполных семей, хоторые являются основным контингентом цтя проведения медицинских абортов по социальным показаниям.

- Необходима широкая пропаганда вреда медицинского аборта, особенно в средствах массовой информации, во всех учебиых заведениях. Вновь надо ввести в обязанность врачей акушеров-гинекологов чтение лекций среди молодежи по этой тематике.

- Обучение, касающесся подростков, цолжно быть налравлено; на обеспечение доступа к информации о репродуктивном, сексуальном здоровье, включая знания о методах предупреждения нежелательной беременности, на половое воспитание, на профитактику СПИДа и других болезней, передаюнихся пононым путем. 
- Для школьников должна быть разработана программа сексуального воспитания - специально для 1, 2, 3 класса и т. д., чтобы не травмиро-

- Summary: The complex rescarch of a condition of health of the women and their children in conditions of the Volgograd region in dynamics of 25-vear's supervision has revealed authentic dependence of infringements somatic, reproductive and neonatal health from size and duration of ccological loading in area of residing. Is established, that with increase of duration of intluence of a high level of ecopollution of atmospheric air the condition of health of the women and their children is worsened, i.e. the effect of the saved adverse action ecopollutants is revealed. It is confirmed recejved by regression models of the high statistical imponance which has proved authentic вать гскхику ребенка излишними знаниями о сексуальной жнзни.

connection between size and duration of ecological loading in area of residing and the basic parameters of health female and neonatal populations. These models are a basis for forecasting frequency of the revealed infringements from a dcgree of ecological loading.

The submitted work is a part of the contribution in the decision of a very urgent problem - ecological reproductology at a level of the Volgograd region having purpose to improve somatic, reproductive health of the women and health of their children, that will promote, at the end, stabilization of a demographic situation. 